tent, depoliticizes Lee's class-based experiences. As one reviewer puts it, [“i]t would be very easy to blame the school's not-so-subtle caste system for Lee's problems and unhappiness, but Sittenfeld doesn't" (Schappell). If the novel does not engage in a criticism of the way elite institutions make class meaningful or a criticism of how class as a systemic factor informs and often obstructs an individual's development, then what does it do? Levinson argues that the American success myth is "sustained by widely disseminated stories, both fact-based and fictional, meant to demonstrate that mobility is largely a matter of individual agency" (22). Does Prep then simply invert the formula of the success myth by individualizing failure and holding Lee responsible for her own immobility?

\title{
4. Diversity, Class, Mobility: Prep's Cultural Work
}

The creation of a neoliberal reader and its ambivalent potential of subverting and affirming neoliberal values is one example of the complex processes of meaning production in which Prep engages. In the following I want to return to the notion of 'cultural work', introduced by Jane Tompkins in her study Sensational Designs: The Cultural Work of American Fiction, 1790-1860 (1985). Tompkins's premise is that cultural artifacts should not be studied for their inherent artistic or literary merit, but "because they offer powerful examples of the way a culture thinks about itself, articulating and proposing solutions for the problems that shape a particular historical moment" (xi). Since my overall research interest in this study is to understand the ways in which the United States via a number of different epistemological channels-institutional, fictional, academic, and aesthetic-makes sense of its own elite educational system, Tompkins's approach seems particularly appropriate and productive. Though I would not necessarily argue that the texts I am considering "have designs upon their audiences" (ibid.) in the sense that Tompkins uses the phrase, I do agree with her conceptualization of novels as "instruments of cultural self-definition" (xvi) and as "agents of cultural formation" (xvii). In the following section, I thus want to focus on the extent to which the novel gives room to questions and issues that preoccupy and destabilize the discourse of elite education.

An important distinction, in the context of Prep, has to be drawn between the measurable cultural work the text has inspired, becoming evident, for instance, in articles, reviews, and blog posts, and the potential for cultural work 
that is inherent in the text itself and might unfold in the process of individual readings. As we have seen, the actual cultural work initiated by Prep, at least to the extent that I was able to trace it in public discourse, is fairly limited. While professional reviewers and lay commentators alike seem to agree that that the novel speaks meaningfully about class and that it is important, if uncommon, to do so in twenty-first-century America, very few of the contributions actually use this impetus in any productive way. Few, if any, connections are drawn between the novel's depiction of the inter-class clash experienced by Lee and the lived experience of many who suffer from the consequences of increasing socio-economic inequality. No one used Prep as a point of departure to interrogate the (elite) educational system with regard to its democratic duty of ensuring upward mobility and equal opportunity for all. Last but not least, only very few articles comment on the protagonist's-and, by extension, the novel's? - disconcerting racism. Furthermore, not one reviewer discussed Prep's complex negotiation of liberal and neoliberal principles and values or commented on the ways in which the text seems to simultaneously affirm and undermine neoliberal narratives of well-deserved success. In the following, I want to complicate Prep's position in the discourse of elite education by discussing the cultural work in which the novel engages with regard to three topics: the issue of diversity, the negotiation of class, and the imperatives of merit and mobility.

\section{The Diversity Paradigm: 'We have girls, we have blacks, we have Hispanics'}

According to its blurb, Prep is "a brilliant dissection of class, race, and gender in a hothouse of adolescent angst and ambition." All three categories inform Lee's experience at the Ault School and are addressed by her repeatedly, in ways that are sometimes insightful, but often problematic. Her account of "Ault's social strata" (14) is not merely descriptive, after all; it is normative. As she expounds on the implications of her classmates' race, ethnicity, geographical background, and gender, it becomes clear quite quickly that she is not only exposing the racism, sexism, and classism of the elite educational space, but also, quite disconcertingly, her own. Ultimately, it is up to the reader to decide which of her sentiments and resentments to attribute to Lee herself, and which to the elite educational space.

Toward the end of her senior year at Ault, Lee receives a note telling her to meet with the school's headmaster, Mr. Byden, who suggests that she be part 
of a New York Times feature on the Ault School. Media attention, Mr. Byden knows, is "always a double-edged sword," especially at a time "when the general public isn't all that enamored with the idea of prep school" (353). He thus asks Lee whether she would be able to provide a "balanced as well as truthful" (354) view of the school, while conveying a sense of pride and gratitude for being part of the Ault community. Per her request, he explains the project:

"[...] Now, the angle of the story as it's been described to me is the changing face of the American boarding school, with Ault functioning as a stand-in for Overfield, Hartwell Academy, St. Francis, et cetera. What they're saying is, these places are no longer enclaves for the sons of the wealthy. We have girls, we have blacks, we have Hispanics. Despite their reputation, boarding schools are mirrors of American society."

"So I would be speaking as a girl?"

"As a girl, or on behalf of any of your affiliations."

I wondered if he thought there was more to me than met the eye - that I was Appalachian maybe. "Are there specific things I should tell them?"

Mr. Byden grinned. I still think of that grin sometimes. "Just the truth." (ibid.)

This exchange is instructive in a number of ways. First, Mr. Byden's comments illustrate Ault's self-perception-or at least the impression the school wants to convey-as a space that fosters diversity, equality, and inclusion. This image is mirrored, incidentally, in Ault's real-world equivalent, the Groton School, which in its mission statement claims to be "committed to diversity and inclusivity," encouraging a "shared examination of our different perspectives [...] especially in terms of race, religion, national origin, gender and sexuality, socioeconomic status, and political ideology" ("Diversity and Inclusion Statement"). It is not surprising, then, that Groton's "Facts at a Glance" section specifies the percentage of students of color-a somewhat remarkable 40 percent. Second, the exchange demonstrates that Mr. Byden feels comfortable mentioning sex, race, and ethnicity, but refrains from addressing the issue at hand: class. This unwillingness can be seen as symptomatic of the treatment of socio-economic factors-or, more precisely, the lack thereof-throughout Ault's "universe of privilege" (175). Mr. Byden clearly wants Lee to speak on behalf of her class background and her position as a scholarship student, but 
he just as clearly does not feel comfortable telling her this. Lastly, the scene illustrates Lee's troubled relationship with her own class identity. It remains uncertain whether she really does not understand the role Mr. Byden expects her to play, which-given her obsession with her own and her peers' socioeconomic backgrounds-would be surprising. Lee's suggestion that she would be speaking "as a girl" again reveals the lingering invisibility of class in comparison with other identity categories-it is hard to imagine Darden Pittard, the token black interviewee, thinking that he was supposed to speak as a boy. Race, then, is visible and expressible in ways that class is not. Lee's reluctance accentuates the unease she feels toward her own social standing as well as her inability or unwillingness to develop an affirmative stance toward her class identity - there is no place for her in the paradigm of diversity.

\section{Prejudice and Racism}

Lee introduces three students of color at Ault by name, one of whom, Kevin Brown-“a skinny chess whiz who wore glasses" (41) - is only mentioned once and in passing. The two others assume parts of some importance in the narrative and can be seen as somewhat crude representations of two types of coping with racial otherness in elite, white surroundings: defiance and assimilation.

Little Washington, a black girl from Pittsburgh, is one of the first classmates Lee interacts with and even considers "trying to become friends with" (13). According to Lee, Little's "blackness made her exist outside of Ault's social strata" (14), which allegedly gives Little "the choice of opting out without seeming like a loser" (ibid.). The reader does not learn much about Little Washington, but what little information is conveyed points to the fact that Little herself might not read her status as affirmatively. ${ }^{10}$ The main narrative arc around Little is her exposure as the thief who has been stealing money from the other students in the beginning of freshman year, and Lee is the one who catches and exposes her, which results in Little's expulsion. It is telling

10 A minor storyline revolves around a student complaining to the head of house, Madame Broussard, that someone "is leaving pubic hair in the bathroom sink" (12). This complaint is voiced several times, though no one seems to take it seriously. Several days later, after talking to Little Washington in the bathroom, Lee notices "a sprinkling of short, coarse black hairs" and concludes: "So they were head hairs, Little's head hairs" (23). This anecdote illustrates the degree of separateness Little encounters as a black girl at Ault, and the ignorance, indifference, and even hostility she faces in her everyday life at the school. 
that the novel opens with a subplot revolving around economic need and inequality, just as it is telling that Lee has no empathy for Little's situation. Little represents an unruly element within Ault's hierarchy, refusing to accept and internalize its perceived structures in the way Lee does. She maintains a critical distance and seems to see through much of what mystifies Lee. When Lee talks to her about Gates Medkowski, a senior whom she admires, Little drily responds: "She's rich. That's what Gates is. Her family has a whole lot of money" (22). While Lee sees only the charisma that accompanies wealth, Little recognizes the economic foundation on which it is built. After Lee has caught her stealing, Little is unapologetic: “Their families are loaded [...]. They don't need the money"' (35). She unsuccessfully tries to appeal to what she believes to be common ground between her and Lee-"You're gonna act like you don't understand? Don't even try to pretend like you're one of them. [...] I can see with my own two eyes you're not paying your way here" (35). The case of Little Washington signals to the reader not only Lee's racism but also the precariousness of her own situation, which makes it impossible for her to show solidarity with her classmate.

The second student of color is introduced as the exact opposite of Little Washington. Darden Pittard is a basketball player from the Bronx, and, according to Lee, "our class's cool black guy" (41)—popular not only because his classmates genuinely like him, but also because "they liked the fact that they genuinely liked a big black guy from the Bronx" (119). Darden, in his "gold chain and rugbies that pulled across his muscular back and broad shoulders" (41) seems to have embraced the role the Ault community wants him to play: racially and culturally other, but comfortably, unthreateningly so. Toward the end of the narrative, the reader learns that this may well have been a conscious strategy of survival, as Darden explains to Lee that "[b]lack people who live in a white world learn to be careful [...]. You learn not to make waves" (387). Whereas Little is expelled and has to leave Ault, Darden goes on to become a lawyer and a trustee for the school, thus signaling that assimilation is still the strategy rewarded by the elite system.

Lee's own racism becomes more obvious in her interaction with Rufina Sanchez, one of the three Latina girls in her class. Rufina, we learn, is so good-looking that Lee would have been "intimidated to talk to her if she were white" (44). Following a stereotypical exoticized description of Rufina's appearance-she "had long wild black hair and swollen lips and dark, thin, arched eyebrows over big eyes, and she wore tight jeans and tight shirts" (167) - Lee elaborates on her surprise that Rufina is dating Nick Chaffee, who 
is part of a group of wealthy male students: "Surely he didn't want to be her boyfriend-Ault guys almost never went out with minority girls, and if they did, it was some geeky guy and some Asian or Indian girl, never a black or Latina girl from a city and definitely never one of the bank boys" (170). When the fact that Nick and Rufina are in a relationship is confirmed, Lee concludes: "Beauty trumped race, apparently" (201). Just as with Little Washington, Lee feels a "mystified admiration" for Rufina and her friend Maria because "they seemed not to care what people thought of them" (170). Again, Lee reads their ethnic otherness as the root of their freedom to "act irreverent"- "while I could pass, their ethnicity made their status as outsiders definitive" (ibid.).

Lee's system of classification also marks Asianness and Jewishness as deviant and thus defective qualities. A case in point is her treatment of her freshman year roommates, Sin-Jun and Dede. Initially, Lee tells us, she was shy and reserved even with Sin-Jun, because she "hadn't yet determined the hierarchies in a way that classified her as unthreatening" (232). For much of the novel, Sin-Jun, originally from Korea, is portrayed as stereotypically Asian: quiet, ambitious, and generally unobtrusive, except for her penchant for strange and smelly food. It should also be noted that just as Little Washington's speech is marked as African American Vernacular English, Sin-Jun speaks broken English during her entire time at Ault. When Sin-Jun tries to commit suicide during junior year, Lee is stunned: "[P]erhaps I'd underestimated her. Perhaps in the past I hadn't given her credit for having opinions or experiencing discontent-for being like me" (213). Immediately, Sin-Jun's social capital increases in Lee's eyes: ["I]n her new incarnation, I found SinJun intimidating. I could imagine her having disparaging thoughts about me" (231). Lee is unable or unwilling to see the racially and nationally different SinJun as an equal and even doubts her humanity-"having opinion or experiencing discontent"-thus again giving powerful testimony of her own racism and Anglocentrism.

While Lee dismisses Sin-Jun as blank and not fully human, she is downright contemptuous of Dede for being "a follower, literally a follower" (11) who tries to ingratiate herself with the cool kids, even though she is "neither rich enough nor pretty enough to be truly popular" (ibid.). When Lee learns that Dede is interested in Cross, her verdict is clear: "Dede had no chance with Cross. Yes, she was rich, but she was also Jewish, and, with a big nose and the last name Schwartz, she wasn't the kind of Jewish you could hide" (45). The reader does not learn much else about anti-Semitism at Ault, but the American elite educational system itself of course has a long history of dis- 
criminating against Jewish students. It seems particularly problematic, then, that we learn toward the end of the novel that Dede ultimately gets a nose job (398), thus perpetuating a host of anti-Semitic stereotypes.

As these examples show, Lee is not merely and observer and chronicler of the racism and anti-Semitism permeating Ault, but an active participant in its construction and perpetuation. It remains unclear, however, where her prejudices originate, because she seems to bring this set of assumptions with her when she arrives. Since she does not tell us anything about overt racism at Ault and we do not have access to anyone's inner life except hers, it is difficult to judge the novel's position toward its protagonist's discriminatory thoughts and practices.

Another relevant axis in Lee's social taxonomy is region. Ranked highest in that hierarchy is New England, ranked lowest the Midwest, Lee's own native land. Other regions are mentioned-Aspeth and Conchita are from Texas, for instance, and Lee mentions some unspecified "Southern students" (351)-but they seem to be unmarked in the taxonomy. "Things are different on the East Coast," Lee tells Conchita during their first conversation, trying to sound nonchalant. Conchita, more open about her attitudes toward her surroundings, admits that when she arrived at Ault, she thought she had "landed on another planet" (69). The difference between the two regions is aesthetic-as Lee points out, "[f]all in the Midwest would be pretty but not overly pretty-not like in New England, where they called the leaves foliage" (6) and it is reflected in the behaviors and values of the people. Even though Lee sometimes acutely perceives the indifference and inconsiderateness of her surroundings- "Easterners really didn't care" (186) — her value judgments are clear: "It was Ault people I wanted to convince" (184).

When she first sees her new English teacher, Ms. Moray, Lee remarks on her "tan and muscular" calves- "the legs of someone who'd played field hockey at Dartmouth" (119). When Ms. Moray tells her students that she grew up in Dubuque and went to the University of Iowa, she immediately falls in Lee's esteem, who now "recognized a certain Midwesternness in her. It was in her clothes, especially the denim skirt, and also in her gestures" (122). In a conversation with Lee, Ms. Moray even remarks on their shared geographical background and "admit[s] to a soft spot for a fellow Midwesterner" since "there aren't a whole lot of us at Ault" (137), but instead of creating a common ground, Lee is horrified. After all, her own Midwesternness is not something she wants to be reminded of, much less claim in an affirmative manner. If the central conflict for Lee is between the Northeast and the Midwest, it is 
because Lee uses region as a cipher for class; that is, she conceptualizes class differences-aesthetic, behavioral, social-in the rhetoric of region.

\section{Gender}

In addition to and conjunction with the racialized categories discussed above, gender is a decisive factor structuring Lee's taxonomy of the Ault School, with regard to social and academic stratification alike. Even though the school is now coeducational, life at Ault is still to an extent characterized by separate spheres and the distinct behaviors, norms, and regularities that accompany them, beginning with the living situation of "four boys' dorms and four girls' dorms" facing each other, "with granite benches in the middle" (7). When Lee visits one of the boys' dorms, she feels "utterly irrelevant, or even worse, like an intruder" because there seems to be no room for girls in the boys' homosocial sphere: "Girls always liked it when boys were around, but it often seemed to me that boys preferred to be by themselves, talking about girls in the hungry way that, I suspected, they found more gratifying that the presence of an actual girl" (150). Again and again, Lee comments on the gendered differences in behavior of boys and girls. ${ }^{11}$ Girls' behavior, overall, seems to be more restricted and regulated; Lee feels, for instance, that she should not eat certain foods-"the more meaty or spicy a food was, the more incriminating to a girl" (126); she is worried to address her issues with Cross because she does not want to be "the kind of girl who always wanted to talk" (367) and is horrified at the prospect of crying in front of him because "girls who cry [...] are so ordinary" (377-8). While the boys seem to need girls only as a backdrop against which to enact their masculinity, girls' behavior seems structured by and dependent on boys: "[T]here would be so many things I'd do for a guy that I wouldn't do in my usual life-jokes I wouldn't normally tell, places I wouldn't normally go, clothes I wouldn't normally wear, drinks I wouldn't normally drink, food I wouldn't normally eat or food I would normally eat but wouldn't eat in front of him" (289).

Lee's observations furthermore show that she herself uses beauty as the first and most important standard against which to measure girls and

11 Examples include: different types of photographs in the yearbooks (sports-related for boys, groups of friends for girls; 20); different ways of greeting (girls hug, boys slap each other on the back; 42); different behavior on the ice rink (girls are gliding around, boys try to knock each other over; 42); girls collectively participating in a prank, boys refraining from joining them; 44). 
women, as for instance when she sees Ms. Moray for the first time and delves into an elaborate description of her appearance: "She wasn't exactly pretty-she had an upturned, vaguely piggish nose, and brown eyebrows that looked even thicker and darker than they were because her chin-length hair was blond-but she was pulled together, kind of sporty" (118-9). Her encounter with Angie Varizi, the New York Times reporter, is structured very similarly, when Lee expresses her surprise at Angie's youth and outfit-jeans and cowboy boots-and then goes on to describe her: "Her straight hair was pulled back in a ponytail, and she had a gap between her front teeth. She definitely wasn't beautiful, but there was something open and intense in her face-she did not seem apologetic about the fact that she wasn't prettier" (356). Lee's internalized sexism becomes even more apparent in her contemptuous descriptions of Sin-Jun's friend (and, later, lover) Clara O'Hallahan, whom she describes as "chubby, annoying" (42), "plump, yappy" (83), and "a heavy girl" (213), and explains her aversion to her as follows: "My real frustration with Clara, I think, was that it seemed that she should be insecure but wasn't" (226).

Given the gendered norms and patterns of behavior Lee encounters at Ault, it is perhaps not surprising that Lee registers the envy she feels toward the boys at her school: "I felt a familiar jealousy of boys. I didn't want what they had, but I wished that I wanted what they wanted; it seemed like happiness was easier for them" (44). She explains that her fascination with some of the boys is not romantic but, in a way, ontological. As a freshman, for instance, watching one of the male seniors give an announcement leaves her with "the sense that I wanted to be Adam Rabinovitz. [...] What I wanted was to be a cocky high-school boy, so fucking sure of the world" (74, my emphasis). This does not mean, however, that Lee is uncritical of the gender dynamics at Ault, or ignorant of the ways in which boys benefit from these structures. She mentions how "boys mocked you in a way that assumed you could not, just as easily, mock them back; they took for granted their own wit, and your squeamishness and passivity" (53). She describes how she hates to be told to calm down by boys as if they assumed she would "leap from my chair to embrace you [or] shriek with delight" (248). And even if she enjoys occasionally being teased by her male classmates, she "resented the way that boys included me as a prop in their exchanges with one another" (251). 


\section{Conclusion: Reproducing the Illusion of Diversity}

As we have seen above, Ault is complicit with the contemporary neoliberal climate with regard to the school's collective acceptance of the diversity paradigm as a leading factor in its self-description. Of course, for places as notoriously discriminatory as private educational institutions, it is a big step to accept students with minority backgrounds and to address it openly and frame it in a rhetoric of affirmation. But, as my discussion of the selective silence around class has demonstrated, gender, race, and ethnicity are written into the school's official script, in part, so that socio-economic factors can be written out. The diversity paradigm is an integral part of the merit narrative of elite institutions and thus of their socio-cultural legitimization. As Michaels poignantly argues, affirmative action and related strategies do not undermine the principles of meritocracy; on the contrary, they create the illusion that a meritocracy exists in the first place (2006: 85):

Affirmative action guarantees that all cultures will be represented on campus, that no one will be penalized unjustly for belonging to a culture, and therefore that the white students on campus can understand themselves to be there on merit because they didn't get there at the expense of any black people. The problem with affirmative action is not (as is often said) that it violates the principles of meritocracy; the problem is that it produces the illusion that we actually have a meritocracy. (85)

By collectively embracing and highlighting the diversity paradigm, elite institutions signify their openness to those who are 'smart enough and/or hardworking enough' and, in so doing, mask their student bodies' continuing socio-economic homogeneity. Ault's headmaster, Mr. Byden, wants to communicate the fact that elite boarding schools "are no longer enclaves for the sons of the wealthy" but rather that they are "mirrors of American society" (354). Of course, one could ask whether reflecting a society that is still riddled with inequality and racism is a reasonable goal; and one could argue, with only a touch of cynicism, that precisely by being "enclaves for the sons of the wealthy" elite boarding schools are, in fact, mirroring a society that has grown increasingly unequal in socio-economic terms since the 1970 s and where, as countless newspapers and media outlets inform us, "the rich always get richer" (Kotlikoff). In any case, Ault's employment of the diversity paradigm as it is portrayed in Prep is perfectly in line with the neoliberal instrumentalization of multiculturalism as a tool to hide class differences. 
As my discussion of Lee's taxonomy of privilege has shown, Prep does, on the level of content, indeed offer an incisive and compelling, if at times problematic, treatment of the politics of identity and discrimination in the elite educational space. A glance at the narrative's deep structure, however, suggests that Prep is, in fact, complicit with the instrumentalization of the diversity paradigm it seemingly aims to expose. On the one hand, this is due to the cast of characters that Lee introduces to the reader: Lee's roommates, introduced in the beginning of the narrative, are Sin-Jun from Korea and Dede, a Jewish girl from New York. The first chapter revolves around Little Washington, a black girl. In the second chapter, Lee talks to her future love interest, Cross Sugarman, who is also Jewish, for the first time. The third chapter foregrounds Conchita Maxwell, a Mexican American girl from Texas, who "mention[s] her Mexicanness [...] often" (101). The fourth chapter introduces Ms. Moray, the English teacher, who is from the Midwest and, as some students are fond of pointing out, "LMC" (360). During the fifth chapter, Lee's Midwestern, lower-middle-class parents come to visit and Lee spends some time with Rufina Sanchez and Maria Oldega, "who were the only Latina girls in our class besides Conchita" (167). In the sixth chapter, Lee gets to know Dave, the "townie" (242) who asks Lee out on a date, an offer she ultimately declines because he is not part of the Ault community. Chapter 7 revolves around Lee's academic failure and introduces the character of Aubrey, her math tutor, about whose socio-economic or racial/ethnic background we do not learn anything. The last chapter focuses again on Lee's relationship with Cross, her college plans, and the New York Times interview scandal, during which she is consoled by Darden Pittard, one of only two black boys in her class. Of course, there are also a number of characters who do not fit into the diversity paradigm-Lee's roommate and best friend Martha, who is from a wealthy Vermont family; Aspeth Montgomery, the grade's 'queen bee', hailing from a wealthy Long Island family; or Nick Chaffee, one of the "bank boys" (170). But the overall image Prep transports through its cast of characters is certainly one of racial, ethnic, regional, and, to an extent, even socio-economic diversity. Thus, even though the novel seems to criticize the homogeneity of the elite educational space, it simultaneously pays lip service to that space's selfdescription as 'multicultural' in all possible senses of the word.

In a similar way, Prep seems to exonerate the institution of charges of racism, sexism, and classism by demonstrating time and again that it is Lee herself who harbors these resentments, not her surroundings. Despite the fact that Lee delivers her judgments confidently and without qualms, the nar- 
rative exposes her misreading of the social order several times. Consider, for instance, Lee's reaction when she learns that Cross is Jewish: "Cross was Jewish? Never once had this occurred to me. But he was so popular, he was senior prefect" (381). According to Lee's taxonomy, Cross's Jewishness should have prevented him from becoming one of the class's most popular boys. As mentioned above, Lee similarly misreads the rules of dating at Ault, when she states that "Ault guys almost never went out with minority girls" (170). She then has to reformulate the rules when she learns that Nick and Rufina are, in fact, dating, and concludes: "Beauty trumped race, apparently" (201). Lee furthermore reveals her own racism when she assumes that Conchita is on scholarship and from a poor family simply because of her ethnicity, or when she is surprised that Sin-Jun, despite her Koreanness and imperfect command of the English language, has a deep and multilayered emotional life. There are a number of additional examples of how the narrative exposes Lee's errors in judgment and, in so doing, to an extent exonerates the institution and the elite community-there is no systemic or collective racism (or sexism, or classism), the novel seems to say, but only the individual prejudices of its marginalized and bigoted protagonist.

\section{The Pervasiveness of the Unarticulable: Class}

In the course of the narrative, Lee gives three different reasons for applying to Ault. The first is academic and sounds like she extracted it from a promotional brochure: "The resources here are incredible-the caliber of the faculty and the fact that the classes are so small and you get all this individual attention and your classmates are really motivated" (358). Given Lee's academic failure and her general lack of involvement in intellectual or extracurricular activities, this is the least convincing part of her self-narration. Her second and more compelling reason is primarily aesthetic-a "sort of dumb thirteenyear-old's idea of boarding school" (357): Lee describes browsing through catalogs whose "glossy pages showed photographs of teenagers in wool sweaters singing hymns in the chapel, gripping lacrosse sticks, intently regarding a math equation written across the chalkboard" (15). The appeal, then, is not purely or even primarily academic but lies in some elusive vision of a different, beautiful, privileged life. "I had traded away my family for this glossiness," Lee concludes: "I'd pretended it was about academics, but it never had been" (ibid.). During the interview, however, Lee shares an anecdote with Angie that translates her diffuse yearning for a particular aesthetics into more con- 
crete, socio-economic terms: On vacation in Florida, Lee and her family drive by a number of huge, beautiful houses, and when Lee-ten years old at the time-asks her parents why they do not live in such a house, Lee's father explains that "people like us don't live in these houses. These people keep their money in Swiss bank accounts. They eat caviar for dinner. They send their sons to boarding school," to which Lee replies by asking whether "they send their daughters to boarding school" as well (363). This, then, is the anecdote that prompts Angie to conclude that Lee was "ready to trade up" (364)-and while it might be something of a stretch to assume that a ten-year-old would think in such categories, it is perhaps not too unusual for Lee to form connections between the houses in Florida, the "glamorous" (358) depictions of boarding schools on television and in magazines, and her own academic standing, and then finally to formulate the plan of applying to Ault and similar schools.

When Lee arrives at Ault and encounters her new classmates for the first time, she immediately senses her own otherness. Even though she has gotten only as far as the school's parking lot, she knows that hers will not be an easy transition: "I realized then how much work Ault would be for me" (16). As I have shown in the last section, Lee's social taxonomy marks race, ethnicity, regional background, and gender, all of which matter in one way or another to Lee's experience of the elite educational space because they inform her behavior and thoughts - toward others as well as toward herself. These categories have in common that they are all, to varying degrees, part of an official discourse of diversity that is embraced and cultivated by the institution and the people who populate it. The discursive blind spot in this enticing vision of a school that paradoxically wants to be both elitist and egalitarian-a "mirror of American society" (ibid.) and yet, somehow, also the production site of its cultural and socio-political leadership—is the category Mr. Byden does not name: class.

\section{The 'Peculiar Dialectics' of Class}

The basic idea behind the notion of diversity is to respect and celebrate different identities and cultures, but class, as we have seen, does not easily fit this paradigm. Poverty, for instance, is not something that readily lends itself to celebration, as Michaels points out: "[W] hat poor people want is not to contribute to diversity but to minimize their contribution to it-they want to stop being poor" (2006: 7). The lower middle class-Lee's class of origin-likewise does not fit the pattern of accentuation and affirmation. Rita Felski describes it as a "nonidentity" (34) and argues convincingly that "the lower middle class 
is no one's fantasy and no one's desire; it has no exchange value in the cultural marketplace" (38). The uneasy position of class as an identity category is rooted in what Gavin Jones, writing about poverty in his book American Hungers, calls a "peculiar dialectics": an oscillation "between material and nonmaterial, objective and subjective criteria" (3). Located at the intersection of discourse, practice, and the body, class thus includes both "the materiality of need" - and, one might add, that of excess and abundance-and "the nonmaterial areas of psychology, emotion, and culture, [...] moving away from the absolute and objective toward the relative, the ideological, and the ethical" (ibid.). Prep, as I will show below, takes a very specific stance on class (and the related notions of merit and eliteness), one that deviates to some extent from the established concepts and narratives in the discourse of elite education. In the novel, class is framed in decidedly individualizing terms, as a category that is located, inescapably, in the body-an ontological category that marks a difference not only of having, but of being.

\section{Articulating Class: Lack, Contrast, and Silence}

To Lee, class manifests itself primarily through lack. On the one hand, this is a lack of material things that signify wealth, as Lee explains to the reporter: "You can tell by people's rooms-whether or not they have stereos, or if the girls have flowered bedspreads, or if they have silver picture frames. Just the quality of their stuff" (361-2). Lee, for instance, owns only generic, beige JCPenney bras (20); her comforter is not flowered but "reversible, red on one side, blue on the other" (35); she does not own a stereo (45); her sweaters are acrylic, not cashmere (235); and she cannot afford to use the school's laundry service. In addition to these material factors, Lee's class also becomes apparent via certain behaviors that signal a lack of money, for instance calling her mother "on Sundays, when the rates were lower" (77), or the fact that she would have to admit that her parents are "driving, not flying, from South Bend" for financial reasons, even though it takes eighteen hours to do so (169).

Perhaps even more important in terms of aggravating her sense of unease, however, is her lack of cultural capital—of specific knowledge and experiences that are regarded as 'normal' in the elite environment she finds herself in: "At Ault, there was so much I didn't know. Most of it had to do with money (what a debutante was, how you pronounced Greenwich, Connecticut) or with sex (that a pearl necklace wasn't always a piece of jewelry), but sometimes it had to do with more general information about clothing, food, or geography" (68). 
For instance, Lee has "never had Thai food before" (46); does not have a middle name (60); has "never ridden a limousine" (100), and only once been in a taxi (60); has "never seen Chanel in real life" (150); has never been to Europe (181), nor even to California (218). Not surprisingly, Lee feels like she does not fulfill the "idea of an Ault student" (218).

This lack is not alleviated by any possible compensatory abundance-of warmth, of fun, of belonging - at home. While Lee initially "sometimes pretended I was in my bed in South Bend and that the sounds of the dorm were the sounds of my family" (10), her growing alienation from her parents and brothers turns her home into a place she is "overwhelmingly relieved to be leaving" (349). Thus, the way her class background becomes meaningful to Lee prevents her from claiming it affirmatively as a source of identity. This, again, fits established narratives of the unattractiveness of the lower middle class. As Helen Chappell points out, "[t]he one class you do not belong to, and are not proud of at all, is the lower middle class. No one ever describes himself as belonging to the lower middle classes" (quoted in Felski 34).

Prep employs a number of strategies to invoke or create class in the narrative. On the one hand, rather straightforwardly, class is articulated through explicit references to money. For instance, after Lee and some other students have spent the surprise holiday at the local mall, somebody suggests taking a taxi back to school, and Lee thinks that she has "less than five dollars left in my pocket, [...]. But no one else seemed concerned about money, and I said nothing" (60). When Conchita's mother invites Martha and Lee for lunch to an upscale restaurant, Lee tells us that it was "oddly liberating to realize I had only fifteen dollars in my pocket-I wouldn't be paying. I wouldn't even try, because I couldn't" (104). These examples illustrate not only how class is articulated in the narrative, but also demonstrate that it is visible and present to Lee at all times. In stark contrast to her own lack of it, money is omnipresent at Ault, but in subtle ways: "Money was everywhere on campus," Lee informs us, "but it was usually invisible" (12):

You caught a glimpse of it sometimes in things that were shiny, like the hood of the headmaster's Mercedes, or the gold dome of the schoolhouse, or a girl's long straight blond hair. But nobody carried wallets. When you had to pay for a notebook or a pair of sweatpants at the campus store, you wrote your student ID number on a form and, later on, your parents got the bill. (ibid.) 
While the ubiquity of money accentuates Lee's lack, its elusiveness and invisibility-"[y]ou caught a glimpse of it sometimes in things that were shiny"-furthers its aestheticization and mythification. To Lee, having money is not merely a neutral fact but inextricably tied to an aestheticized vision of a beautiful life-for instance when she imagines Cross's family Christmas: " $[\mathrm{H}]$ is family was probably the kind that had a tree with only white lights and glass ornaments-and how all of them probably drank scotch together and gave one another not tube socks and plastic key chains but leather wallets and silk ties" (332). Or when she reflects about Aspeth: "I thought of Aspeth's long pale hair, the clothes she wore-now that it was spring, pastel button-down shirts and khaki skirts and white or navy espadrilles-and her tan, shapely legs and the light sprinkling of freckles across her nose, which always made her look as if she had spent the afternoon playing tennis in the sun (83)." In these instances, Lee romanticizes the moneyed life in a manner that leaves no room for an equally satisfying existence on more modest means. This life of "leather wallets and silk ties" coupled with "afternoon[s of] playing tennis in the sun" is further put into focus by recurring references to its opposite-the dinginess of "a bowling alley in Raymond" (241), "tube socks and plastic key chains" (332), or Lee's mother's "ratty robe" (331). Lee is utterly unable to counter her image of the beautiful life of the upper class with a halfway decent vision of her own class of origin-a class that, according to John Hartley, "attracts no love, support, advocacy or self-conscious organization" (quoted in Felski 41).

Prep furthermore frequently uses direct or indirect contrasts to actualize class and, in so doing, creates a stark binary opposition of two class positions: On the one hand, Lee's background, in which money (and the lack thereof) matters and which is associated with ugliness, scarcity, pragmatism, and crudeness, and on the other hand Ault's "universe of privilege" (175), in which sophistication, abundance, and insouciance reign. While money and possessions have meaning to Lee, most of her peers exhibit utter disregard for their expensive belongings. For instance, when a classmate cuts a pillowcase in the course of a prank, Lee describes the "casual sacrifice of a pillowcase in the service of a joke" and the fact that there was "so little attention paid to the fact that pillowcases, like everything else, cost money" as "distinctly Aultish" (93-4). Similarly, she finds herself dumbfounded by the way others treat their expensive possessions: While she is waiting in Aspeth's room, Lee notes that "on the floor in front of the door there was a gray peacoat with satin lining, 
which Aspeth stepped on-stepped on, with her shoe-as we exited the room" (150).

In a similar way, Ault is juxtaposed with the specter of the public high school Lee would have attended in South Bend. While the former is characterized by beautiful buildings with "enormous room[s] with twenty-foot-high Palladian windows [...] and mahogany panels on the walls" (3), the latter looms large in Lee's imagination as a place with "hallways of pale green linoleum and grimy lockers and stringy-haired boys who wrote the names of heavy metal bands across the backs of their denim jackets in black marker" (15). Marvin Thompson High is introduced as Ault's polar opposite in every way, and thus works as a means of further contouring the elite educational space. While Ault is distinguished by beauty, taste, and distinction in aesthetic and other terms, the public high school has a cafeteria with floors of "mustard-colored linoleum with black and gray flecks; the sports teams were called the Vikings and the lady Vikings; there was an ongoing debate about whether to let the pregnant girls attend classes after they started to show" (265).

Perhaps the most painful contrast for Lee is that which involves her parents. After they have driven to Massachusetts to visit Ault for Parents Weekend, Lee meets them at the gate to guide them to a less-frequented parking space because she does not want anyone to see "their-our-dusty Datsun" (177). When she gets in the car, she notes that "it smelled like car trip, stuffy and sour. An empty Burger King bag rested on the seat, and several soda cans rolled on the floor. I could not suppress a comparison between this and the kind of food Martha's parents brought on their drives from Vermont: vegetable soup in thermoses and cracked-wheat bread and cut-up fruit that they ate with their real silverware from home" (178). On the same weekend, Lee's parents meet a classmate's family and, again, the Lee emphasizes the contrast with regard to style and status. Moreover, the differing regional backgrounds add to the overall disparity, as does the marked speech pattern of Lee's father:

"Where are you folks from?" my father asked. "Princeton," said Nancy's mother. She was wearing a silky maroon skirt with a swirling paisley pattern and a maroon sweater set, and Mr. Daley was wearing a suit. My own parents dressed more nicely than they usually were on a Saturday, my father in khaki pants and a khaki blazer (surely, since they were not part of the same suit, that was some sort of faux pas) and my mother in a red turtleneck and a gray corduroy jumper. Over the phone, I had haltingly explained to my mother that most parents dressed up; I had felt unable to request that they should, 
but she had understood. "We're from South Bend, Indiana," my father said.

"Just got in about an hour ago, and we're damn glad to be here." (184)

The articulation of class in Prep is thus mainly achieved through the use of contrast. It is important to note that the two poles employed in these contrasts refer to the upper middle class on the one hand and the lower middle class on the other. More extreme class positions-the lower classes or working poor and the extremely rich-are largely eclipsed. This is symptomatic of much of the fictional and discursive treatment of class in the US.

While Lee thinks a lot about class and uses it as her primary category of structuration, the novel also illustrates the silence around issues of socioeconomic stratification. Class, as mentioned above, is not an established category in the paradigm of diversity, and, since it is not a marker that can be claimed affirmatively-Michaels points out that "your ethnicity is something that you can be proud of in a way that your poverty or even your wealth [...] is not" (84)-the silence surrounding it is all the more pervasive. The lack of openness and communication surrounding issues of class is part and parcel of Lee's troubled relationship to her own socio-economic background. She does not, for instance, talk to anyone about being a scholarship student: "In four years, the only people I'd ever talked to about this were Mrs. Barinsky, who worked in the admissions and financial aid office, and Mrs. Stanchak. I'd never even discussed it with Martha" (359). During graduation week, Dede tells Lee "in a strangely beneficent way" (401) that she could have helped her out financially had she known that she was on scholarship. This is interesting in particular because it suggests that Lee's otherness was less visible than she thought.

Lee's status as a scholarship student, unlike her status as a member of the lower middle class, might conceivably be thought of as a source of pride due to its association with merit and achievement. Lee, however, is ashamed, as she explains after the New York Times article made her status public: "Being on scholarship was bad, being unhappy was worse, and admitting to either one was worst of all" (370). Martha and Lee also never discuss the fact that Lee frequently borrows Martha's clothes, but never the other way around (252). Much of the class-related silence is rooted in the shame Lee feels about her background, her difference, her need. According to Felski, shame is "a relevant concept for analyzing a range of experiences of dislocation, including those of class" (39). Shame is an other-directed emotion that is triggered by a fear of infracting "social codes and a consequent fear of exposure, embar- 
rassment, and humiliation" (ibid.). To Lee, shame is the "largest and truest" of her emotions: "[I]t was a rock in my gut and would remain with me" (242).

Lee's own unwillingness to talk about class is mirrored by a refusal to acknowledge class in the Ault community. As Lee soon realizes, however, this refusal extends only to some positions in the class hierarchy and not to others: After being picked up by a limousine, Lee finally realizes that her friend Conchita is not a scholarship student from a family of poor Mexican immigrants, but in fact the daughter of an extremely wealthy oil tycoon. After their visit to Boston, Martha and Lee talk about Conchita's position at Ault and Lee asks why the school lets Conchita have a single room and a telephone-privileges denied the other students. Martha "held out one hand and rubbed her thumb up and down against the other fingers. 'Ault is probably salivating at the thought of all the science wings and art studios the Maxwells can build" (106). Initially, Lee is surprised at the openness with which Martha discusses the Maxwell's financial standing. But after she visits Martha's family's house and realizes "that they, too, clearly were wealthy" (106), Lee learns an important lesson about class and the norms governing the discourse of class in the United States, namely that there are "different kinds of rich" (107): "There was normal rich, dignified rich, which you didn't talk about, and then there was extreme, comical, unsubtle rich-like having your dorm room professionally decorated, or riding a limousine to Boston to meet your mother-and that was permissible to discuss" (ibid.).

In fact, one could argue that in order for the system to work, it is not merely "permissible" but necessary to talk about-in the manner of gossip, complaint, or envy-the very rich. Michaels, for instance, explains what the fact that he is "confronted on a daily basis by the spectacle of people who are much richer than he is" (2006: 192) does to his own class-consciousness: It makes him "feel poorer" (ibid.). Thus, when he reads stories about extremely wealthy people and their lifestyles, it does not only make him feel predictably envious and resentful, but it creates what he calls a "deeply legitimating disidentification" (2006: 193):

He could never afford to do that! [...] Why is this disidentification legitimating? Because it leads Walter Benn Michaels to think of himself as not rich; it leads him to think that when he talks about the problem of economic inequality, he is not the problem, the superrich are. And, of course, the superrich are part of the problem. But, unfortunately, he is too. Compared to the superrich, he may feel poor, but feeling poor doesn't make you poor. (ibid.) 
On a smaller scale, students like Conchita-the "extreme, comical, unsubtle rich"-make students like Martha- "the normal [...], dignified rich"-feel less privileged and so create a sense of normalcy with regard to a certain degree of wealth and privilege, effectively masking its remoteness from the overwhelming majority of Americans.

\section{Being Different: Class and Affect}

Prep begins with Lee's interpretation of her own story: "I think that everything, or at least the part of everything that happened to me, started with the Roman architecture mix-up" (4). This first sentence is instructive in several ways. First, it portends the passivity that characterizes Lee's position in the novel- "everything that happened to me" (my emphasis)—she does not see herself as an active agent in her own narrative. Second, it suggests a degree of randomness in the progression of events unfolding in Prep-the misunderstanding between Lee and her teacher is a "mix-up," after all, and as such incidental, unexpected, seemingly not systemic; it could just as easily not have happened. Third, the incident referred to- "the Roman architecture mixup"-is the first scene in which Lee's socio-economic background assumes a meaningful role in her story, thus pointing to the importance of class in the overall scheme of the novel. The incident takes place four weeks into Lee's freshman year in her Ancient history class. Students are doing presentations on different subjects, and it turns out that Lee has accidentally prepared the wrong topic: She was supposed to present on athletics, but focused on architecture instead. Her teacher then asks her to give the presentation anyway, but because one of her classmates had already done so, Lee feels unable to continue: "I paused. Ever since childhood, I have felt the onset of tears in my chin, and, at this moment, it was shaking. But I was not going to cry in front of strangers. 'Excuse me,' I said, and I left the classroom" (6). Lee's anxiety, manifesting itself bodily and in her inability to communicate properly and convincingly the misunderstanding, is rooted in the feeling of not belonging, of being fundamentally 'other' than her peers.

The solution Lee envisions for the problem of class difference is class passing. Passing is a form of identity negotiation and impression management in which individuals proactively or reactively employ certain presentational strategies to "transgress social boundaries" and be regarded as a member of a different social group (Renfrow 486). The concept is most frequently discussed with regard to race and, perhaps to a lesser extent, gender, and in both con- 
texts it is often stigmatized, seen as either traitorous or deviant behavior. In the context of class, passing is framed differently-it is "not often not noticed or examined," as Gwendolyn Audrey Foster points out, and "essentially viewed as normative behavior" (2003: 102). A society that encourages everyone to conceive of themselves as part of the middle class naturally also encourages class passing in order to ensure the success of this collective fiction.

Normative and normalized, even "celebrated" (Foster 2005: 4), class passing is an integral part of everyday American socio-cultural practices. As Daniel G. Renfrow points out, however-and as Prep poignantly illustrates-"identity negotiations may be emotionally costly" (488). For Lee, they are costly not only because her desire to be different threatens her sense of self and produces anxiety and alienation, but also because she is ultimately unsuccessful and feels her insufficiency acutely and permanently. Beginning with the "Roman architecture mix-up" during which Lee is "uncovered" (6) as different, her failure ends with the catastrophic New York Times article that makes her into "the precise opposite of the person I had, for the last four years, tried to be" (370). Thus the entire narrative is framed by Lee's attempts to negotiate her class identity and come to terms with the markers of her difference: a present absence, denied discursively but actualized bodily, materially, and emotionally.

Michaels laments what he sees as a fundamental conceptual misunderstanding of the category of class on the part of almost everyone who talks about it, exemplified by the Class Matters series of The New York Times:

Indeed, at one point in the series, the Times started treating class not as an issue to be addressed in addition to (much less instead of) race but as itself a version of race, as if the rich and the poor really were, as Fitzgerald thought, different races, and so as if the occasional marriage between them were a kind of interracial marriage. Indeed, the only thing missing was an account of the children of mixed (wealth) marriages, half rich, half poor, confronting a world in which they can't quite find a place. And, actually, the Times even provided a version of that in its profile of one of the (rare) people who has moved up in class, treating her predicament with all the pathos of the tornbetween-two-worlds "not fully at ease"-in-either stories that have been a staple of American literature since the first tragic mulatta found herself at home nowhere. Americans like stories in which the big problem is whether or not you fit in. (2006: 9) 
Prep engages in exactly the kind of practice Michaels criticizes so vehemently: a 'racialization' of class. When Lee arrives at Ault, she immediately senses her difference-a difference not only resulting from material factors (or the lack thereof), but from her very being, her body, her mind. Class, to her, is not just a material category, measured by one's relationship to the means of production, one's income or wealth. Lee experiences her upper-(middle-)class peers as categorically different-she feels "wracked at the impossible gaping space between" her and them (162). Lee thus perceives her own otherness not merely as a difference of having (things, experiences, access), but one of being. Class is turned into an ontological category; it is inscribed into her body.

She does not, initially, see this as a fixed and immutable difference, however, but envisions her own transformation: "I'd imagined that I could lie low for a while, getting a sense of them, then reinvent myself in their image" (6). As we learn over the course of the following four hundred pages, she fails in this endeavor. During brief moments her otherness seems less pronounced; shortly before Parents Weekend, for instance, Lee describes her "sense of belonging" as "acute" (175), attributing this change of perception to her parents' impending visit and her conviction that they, in turn, would not belong. But these moments are fleeting. When Lee is in the transitional space of the airport, on her way home, she feels "more aware of myself as a prep school student that I did at any other time," but, as she points out in the same breath, she is referring to a "subculture I felt I belonged to only when I was away from it" (234).

If Lee thus feels "all the pathos of the torn-between-two-worlds 'not fully at ease'-in-either stories" that Michaels so cavalierly dismisses, one of the main reasons seems to be that she is incapable of imagining and embracing a hybrid identity. Her project of self-making at Ault relies on an attempt at selferasure: Lee feels as if she can only belong if she denies her pre-Ault self completely. But because her class identity is inscribed into her body, erasing her old self is problematic, if not impossible. The physical dimension-the embodiment of class-becomes obvious in the way Lee's body rebels against her attempted self-negation. Whenever she finds herself in a situation in which she would have to perform her reimagined self, her body fails her: "My unease was rising around me like smoke. By the time I reached the dining hall, I was choking on it; I couldn't go inside" (293). When she tries to initiate a conversation, her heart rate increases $(41 ; 96)$; she feels "a swelling in my chest" (25), heat spreading over her face (133). Over the course of the narrative, whenever Lee feels challenged academically or socially-whenever she 
feels that her pre-Ault self is addressed, she responds physically, affectively, lacking control or agency: Her heart "lurched" (4;341), "pounded" $(25 ; 42 ; 184)$, "jumped" (27), "seized" (131), "pinch[ed]" (222), "quicken[ed]" (285), "stopped" (287), "hammered" (369), "thicken[ed]" (400). In social situations, she tries to tell herself to "just be calm [...] to concentrate only on the immediate task in front of me and not give in to the sense that this moment was a monstrous pulsating flower, a purple and green geometrical blossom like you might see in a kaleidoscope." But, again, she is unable to even speak because "my anxiety was exploding, the flower was swirling outward infinitely" (236-7). Similarly, in academic contexts her body makes it impossible for her to act appropriately: In one situation, she is supposed to read her homework to the rest of the class, but finds herself unable to: "I found that I could not. I just couldn't. I knew that my voice would come out quivery and breathless and that my consciousness of this fact would only exacerbate it until, ultimately, my own agitation would make it physically impossible to endure another second" (134).

Unable to integrate the two facets of her personality into a hybrid whole, she blames her surroundings. She feels resentment toward her parents because they anchor her to her pre-Ault self: "I hated them because they thought I was the same as they were, because if they were right, it would mean I'd failed myself, and because if they were wrong, it would mean I had betrayed them" (336). But she also resents the Ault community: "I hated them all at this moment, the indifferent students and faculty and the inconsiderate parents and my own family, for being somehow reliant on kindness that wasn't extended" (193). This duality again illustrates her inability to conceive of a hybrid identity.

\section{Conclusion: The Paradox of Elite Campus Fiction}

Michaels reads Prep as a literary symptom of the neoliberal desire to keep class structures intact, arguing that this desire becomes manifest either in "pretending [class] doesn't exist" or, more often, in "pretending it does exist" (my emphasis), particularly in socio-economically homogeneous places like elite universities. Most importantly, Michaels concludes, this desire invariably finds expression in insisting "that class doesn't matter, or [in redefining] class so that it looks like culture" (2006: 109-10). In this context, then, he regards Prep as an expression of the neoliberal imagination. Can we fault the novel for reinforcing the myth of class diversity at elite institutions through its very structure as a scholarship novel? Certainly; it is surely no coincidence that 
the overwhelming majority of narratives (both literary and audiovisual) that are set in elite educational surroundings follow this blueprint, thus offering cultural visibility to a phenomenon that is statistically still exceedingly rare. As I hope to have shown in my discussion of the fault-lines of class in Prep, however, the novel insists that class does matter, and that it matters quite a bit. Lee's entire experience of the elite educational space is informed by her class background and its socio-cultural and economic ramifications. Furthermore, while Prep's framing of class might seem more cultural than economic, the text does not decouple the two dimensions, and it certainly does not make the claim that classism, or class discrimination, is the dominant issue for Lee.

Michaels is right in arguing that it is theoretically flawed and politically problematic to strip class of its material dimensions by reducing it to cultural and psychological factors, and conceptualizing it analogously to race and gender. And yet, denying or trivializing these factors, as Michaels seems to do, is similarly unsound. After all, the cultural repercussions of class amount to more than condescension and intolerance, as sociologists like Pierre Bourdieu have pointed out in a variety of contexts. Lee's problem is not only that her otherness is painful and isolating; her problem is that it is debilitating. Her lack of social and cultural capital arrests her development and nullifies her every chance of mobility. By portraying class as a form of embodiment, Prep demonstrates the complexity of social stratification and the various non-economic channels through which elites reproduce themselves. It is somewhat disconcerting that Michaels-who, quite tellingly, does not mention Bourdieu even once in The Trouble with Diversity - completely ignores these processes and, instead, belittles the very real cultural reverberations of socio-economic stratification as neoliberal window dressing.

In this context, Prep also illustrates the central paradox of elite campus fiction. Even though one of the main attractions of the elite campus novel arguably lies in its promise of providing the reader with a glimpse behind the ivy-covered walls of elite institutions and some insight into the privileged lives of the wealthy few, Prep illustrates that this kind of imaginary class transcendence is not easily achieved. This is due to the very nature of the notion of eliteness: as a concept, eliteness fully unfolds only from a distance-it is relational, not absolute. Elite campus novels promise to cover that distance and tell us what it is really like in the "mythological hinterland" (Bradbury 1990: 50) of the elite community. The attempt to approach the elite through narrative, however, demonstrates the necessity of distance: without it, there is no elite. Of course it is still possible to pinpoint and describe certain cri- 
teria that belong to the narrative of eliteness-academic or extracurricular achievement, for instance-but the aura of eliteness vanishes through proximity. This is why most of the more recent elite campus novels employ a nonelite focalizer-protagonist, like Lee, who creates the necessary distance and whose voyeuristic gaze we can adopt. The paradox, then, is that because of this, these stories ultimately fail to deliver on their initial promise: We learn much more about middle-class desires and anxieties than we do about the elite, which remains intact but out of reach.

\section{'Smart, Disciplined, Driven': Merit/Mobility}

Another productive lens through which we can examine the negotiation of class in Prep is the notion of mobility. Mobility-upward and downward-is one of the central paradigms framing the conceptualization of class in the United States, and recent analyses, as Jones points out, have increasingly focused on "the relational and contingent aspects of class as a category" and on "its capacity to be transcended" (12). In Prep, mobility as the vertical movement of potential class transcendence is linked to actual movement through the land, particularly the journey from the Midwest to the Northeast, as Lee's retelling of her arrival at Ault demonstrates:

In mid-September, weeks after school had started in South Bend for my brothers and my former classmates, my father drove me from Indiana to Massachusetts. When we turned in the wrought-iron gates of the campus, I recognized the buildings from photographs-eight brick structures plus a Cothic chapel surrounding a circle of grass which I already knew was fifty yards in diameter and which I also knew you were not supposed to walk on. Everywhere there were cars with the trunks open, kids greeting each other, fathers carrying boxes. I was wearing a long dress with peach and lavender flowers and a lace collar, and I noticed immediately that most of the students had on faded T-shirts and loose khaki shorts and flip-flops. I realized then how much work Ault would be for me. After we found my dorm, my father started talking to Dede's father, who said, "South Bend, eh? I take it you teach at Notre Dame?" and my father cheerfully said, "No, sir, I'm in the mattress business." I was embarrassed that my father called Dede's father sir, embarrassed by his job, embarrassed by our rusty white Datsun. I wanted my father gone from campus as soon as possible, so I could try to miss him. (16) 
The scene is structured by a movement through a number of marked spaces, beginning with the journey from west to east: "[M]y father drove me from Indiana to Massachusetts." Indiana here represents Middle America, in both geographical and socio-economic terms, while Massachusetts evokes associations of old New England, Boston Brahmins, and the Protestant establishment. As before, class differences are coded in spatial, regional language. The fact that they are driving, not flying, carries meaning as well, and is commented on later in the novel, when Lee is afraid that her peers will learn about her parents' means of transportation. There is a strikingly similar scene in Tom Wolfe's I am Charlotte Simmons (2004), in which Charlotte and her parents likewise drive rather than fly to Charlotte's university-in a pick-up truck, no less-and Charlotte is mortified when her father talks about the journey with her roommate's wealthy parents, who, of course, took a private jet. Lee and her father then "turned in the wrought-iron gates of the campus" and encounter "eight brick structures plus a Gothic chapel surrounding a circle of grass"-a description evoking classic New England collegiate imagery, the buildings and grounds of the school serving as visual instantiations of its wealth and tradition. The movement through the gates furthermore signifies the entry into a space that is different, distinct, and removed from the world Lee inhabited before. They meet her roommate Dede's father, who, upon hearing that they came from South Bend, Indiana, assumes that Lee's father teaches at Notre Dame. When her father corrects him by pointing out that he is a mattress salesman, Lee is embarrassed. Her understanding of her own class background includes not only material dimensions-"our rusty white Datsun"-but also forms of cultural capital: her father's occupation, his polite deference, his entire demeanor. Class thus immediately becomes the dominant category Lee uses to make sense of herself and her surroundings, and, as she realizes immediately, it is articulated through a number of different channels.

Geographical mobility here holds the promise of class mobility, but Lee is unable to translate this potential into reality. In the negotiation of her own class identity, Lee is stuck in a liminal place: a foot each in both worlds, at home in neither. Her liminality arrests her possible mobility. Thus, even though the prospect of leaving her class of origin seems to have been at least part of her motivation to apply to Ault in the first place, she fails in attaining the necessary credentials. She realizes, however, that there are other kids at the school who manage this process more successfully: 
There were other kids at Ault I had a feeling about, kids who came from poorer families than I did and would probably grow to make a lot more than I would-they'd be surgeons, or investment bankers. But making a lot of money didn't seem like something l'd be able to control; I'd gotten as far as Ault, but I wasn't sure l'd get any further. I wasn't smart or disciplined the way those kids were, I wasn't driven. (322)

Lee's social mobility ends with her physical arrival at Ault; she remains static after she has entered the elite educational space.

The criteria Lee names-intelligence, discipline, ambition-are part of Ault's official narrative of merit. The imperatives that fuel this narrative are written into the school's official incentive structure, supported by teachers, encouraged through grades, prizes, privileges, and rewarded with positions in the school hierarchy. In addition to the academic and extracurricular distinction expected from the students, the school's official master narrative also includes a set of values meant to legitimize the advantages guaranteed by an Ault education: "In chapel, the headmaster and the chaplain spoke of citizenship and integrity and the price we had to pay for the privileges we enjoyed. At Ault, it wasn't just that we weren't supposed to be bad or unethical; we weren't even supposed to be ordinary" (13). In this scenario, merit becomes the motor that drives mobility and turns kids from poor families into surgeons and investment bankers. We learn that Lee fully conformed to the ideal of the deserving student before she arrived at Ault: "Back in my junior high in South Bend, Indiana, many classes had felt like one-on-one discussions between the teacher and me, while the rest of the students daydreamed or doodled" (5). The contrast between the personality the reader experiences during Lee's time at Ault and the one she claims to have had before could not be starker: "Back in South Bend, both in class and at home with my family, I had been curious and noisy and opinionated. I had talked like a normal person, more than a normal person" (53). At Ault, however, Lee tells us that she is living her life "sideways. I did not act on what I wanted, I did not say the things I thought, and being so stifled and clamped all the time left me exhausted; no matter what I was doing, I was always imagining something else. Grades felt peripheral, but the real problem was, everything felt peripheral" (40).

With regard to the official narrative of merit, Lee fails quite spectacularly. From the beginning, she is overwhelmed by the competition and feels unable to participate in her classmates' struggle for distinction: "Here, the fact that I did the reading didn't distinguish me. In fact, nothing distinguished me. 
And now, in my most lengthy discourse to date, I was revealing myself to be strange and stupid" (5). Even though she does the work, her grades continue to slip and she rarely participates in class discussions because "someone always expressed my ideas, usually in a smarter way than I could have, and as time went on, the less I spoke the less it seemed I had to say" (123). Lee realizes that this development is, in part, due to the change of environment and her inability of coping with it:

It was not clear to me how l'd arrived at this juncture gradewise, because before entering Ault, l'd never received lower than a B plus in any class. Either Ault was a lot harder than my junior high had been, or I was getting dumber-I suspected both. If I wasn't literally getting dumber, I knew at least that l'd lost the glow that surrounds you when the teachers think you're one of the smart, responsible ones, that glow that shines brighter every time you raise your hand in class to say the perfect thing, or you run out of room in a blue book during an exam and have to ask for a second one. At Ault, I doubted that I would ever need a second blue book because even my handwriting had changed-once my letters had been bubbly and messy, and now they were thin and small. (37)

Lee's failure to live up to the standards set by the merit narrative not only includes her academic performance, however, but also her lack of extracurricular achievements and, as the discourse of distinction has it, 'leadership qualities': "I literally wasn't anything, not a chapel prefect or yearbook editor or sports captain [...]. The summer after our junior year, I had gone through a class list to try to find anyone similarly undistinguished and had come up with only two other people" (304).

The official narrative of merit-favoring hard work, dedication, and selfdiscipline-is complemented by an unofficial narrative, an elusive set of imperatives that fascinate Lee because they are hard to grasp, and harder yet to emulate. This set of imperatives relates less to actual, quantifiable achievements, but rather describes a certain attitude that is projected outward, a pose, a performance of being. Lee has difficulties finding the words to describe this phenomenon; she variously refers to "unself-consciousness" (18), "breeziness," "ease," and being "casual" (162) and "adored" (297). An additional important ingredient-and "an Aultish thing" (228), according to Lee-is a sense of self-control and mastery, a sense of being a little "distant" (ibid.) from one's surroundings. The closest Lee comes to articulating this unofficial code is when she reflects on the cultural meaning of sports: 
Sports contained the truth, I decided, the unspoken truth [...] and it seemed hard to believe that I had never understood this before. They rewarded effortlessness and unself-consciousness; they confirmed that yes, there are rankings of skill and value and that everyone knows what they are [...]; they showed that the best thing in the world was to be young and strong and fast. (320-1)

By mentioning the ineffability of this 'truth,' Lee points to a central fault line in the narrative of merit, namely that it rewards not only behaviors and achievements that are measurable and can be attained via hard work, but also these other unnamable things-practices and postures that, as Lee's examples shows, are difficult to mimic and make one's own. Of course, contrary to Lee's observation, sports do not actually reward effortlessness, but rather an attitude or projection of effortlessness. This is reminiscent of the notion of sprezzatura, a concept developed by the Italian Renaissance author Baldassare Castiglione in his 1528 courtesy book Il Cortegiano. In the book, a number of members of the court of the Duke of Urbino discuss the qualities an ideal courtier must possess. One of them, Count Ludovico, claims to have found the "universal rule:"

I have found quite a universal rule which in this matter seems to me valid above all others, and in all human affairs whether in word or deed: and that is to avoid affectation in every way possible as though it were some very rough and dangerous reef; and (to pronounce a new word perhaps) to practice in all things a certain sprezzatura [nonchalance, disdain, or carelessness], so as to conceal all art and make whatever is done or said appear to be without effort and almost without any thought about it. (quoted in Nikulin 165)

This combination of seeming effortlessness and unself-consciousness is exactly what fascinates Lee about some of her classmates, and it is exactly the kind of quality rewarded by the elite educational system. It is crucial to note, however, as Victoria Kahn does, that sprezzatura is "not a quality but an ability"-thus, it cannot simply be described or claimed, but "it must be enacted," performed (156).

This again points to the importance of the body. Sprezzatura is located in the individual's body; it is a sense of "ease of manner, studied carelessness" ("sprezzatura") that is actualized physically. Shamus Rahman Khan, in his book Privilege: The Making of an Adolescent Elite at St. Paul's School (2011), describes a very similar phenomenon, which he calls "embodied ease" (2011: 121). 
Khan argues that students at elite schools "cultivate [...] a sense of how to carry themselves, and at its core this practice of privilege is ease: feeling comfortable in just about any social situation" (2011: 15). In Prep, Lee observes "with a kind of awe" her classmates' versatility, "the many sets of behavior in their repertoire" (326). She herself lacks this fluidity: "I was always me" (ibid.). Khan calls this "corporeal knowledge" (2011: 121) and argues that it becomes "inscribed upon the bodies of students" (2011: 16). Unlike cognitive knowledge, which is relatively easy to transmit or get access to, corporeal knowledge is built through years of individual experience and thus "hard to embody or mimic" (2011: 121). If Jones argues that "poverty is ultimately marked on the body, as hunger or as physical suffering" (3), then the opposite is true for wealth and privilege; they, too, are marked on the body-in the form of sprezzatura or embodied ease, for instance-but they are marked not as lack but as abundance, not as suffering, but as pleasure and ease, as a freedom to move and claim space.

The ambiguity of this form of embodiment lies in the oscillation between concealment and perception, as Victoria Kahn points out: "This [...] necessarily introduces the question of the audience, for to be successful the courtier must conceal his artfulness, but for it to be appreciated as sprezzatura, his concealment must be perceived" (156). In Khan's account of the students at the elite St. Paul's school, this ambiguity is navigated through a distinction between discursive and bodily work: "Hard work was a frame [...] that students mobilized to code their advancement within hierarchies, but this frame did not involve an attendant corporeal display of effort. Their displays were meant to be just the opposite: full of ease" (2011: 120). It is in this ambiguity between discourse and body, hard work and ease, where 'eliteness' resides. Lee herself does not master this dual effort, but she recognizes and admires it in others.

\section{Subverting the 'Normalcy of Mobility'}

In her reflection on the seemingly "singularly boring identity" (34) of the lower middle class, Rita Felski addresses some of the peculiarities that distinguish class from other identity categories. Like Michaels, she points to "an important and inevitable tension between class analysis and the logic of identity politics, because class is essentially, rather than contingently, a hierarchical concept. Any form of class politics is ultimately concerned with overcoming or at least lessening class differences, not with affirming and celebrating them" (9, my emphasis). While race and gender "often mark identity inescapably" 
(Felski 38), class seems more contingent a signifier, more readily amenable to influence either via strategies of class-passing or actual changes in one's class position. Class, according to Felski, however, is more than just "the sum of its material manifestations" (ibid.), and her approach of "focusing on the psychic as well as the social, semiotics as much as economics" (34) seems to me particularly productive, demonstrating that it is, in fact, possible to account for the specific singularities of class as an economic-material category without completely negating its cultural and psychological ramifications.

Felski's piece echoes the dominance of the motif of mobility in the conceptualization and study of class. In the American context, particularly, class is often conceptualized as a dynamic category, and the belief in (upward) mobility is widespread and persistent-all evidence to the contrary notwithstanding. Michaels refers to "[m]any polls [that] show that Americans characteristically think of themselves either as already having moved up in class [...] or as being about to move up in class" and points out that roughly 64 percent of Americans between eighteen and twenty-nine "thought it was either very likely or somewhat likely that they would become rich" (2006: 193). Felski herself mentions the "permeability of class boundaries" and the "possibility of moving up or down the class hierarchy" (38). She also problematizes this dominant mode of theorizing class, and, by discussing Carolyn Steedman's Landscapes for a Good Woman (1987), demonstrates that while mobility might be possible in economic terms, the "psychic markings" of one's class background can prove much more tenacious, sometimes even paralyzing (39). To frame discussions of class in the rhetoric of vertical movement, flexibility, and contingency and to conceive of one's own class position as transitional, ephemeral, and subject to change is such a widespread discursive practice that Jones calls it the "normalcy of mobility" (12). Lee herself offers an estimation of her situation in the fall of her junior year:

I wondered if I had also changed since our freshman year. Certainly not as successfully - I was less naive, a little less anxious, but I was fatter, too, I'd gained ten pounds in the last two years, and also my identity felt sealed. Early on, I'd imagined I might seem strange and dreamy, as if I spent time alone by choice, but now I was just another ordinary-looking girl who hung out most of the time with her roommate (similarly ordinary looking), who did not date boys, did not excel in either sports or academics, did not participate in forbidden activities like smoking or sneaking out of the dorm at night. Now I was average and Rufina was happy. (173) 
Her identity, she tells us, feels "sealed." There is no room for movement or transformation; the "permeability of class boundaries" (Felski 38) has proven to be either non-existent or unattainable for Lee. Our assessment as readers resembles Lee's. We have experienced her academic and social failures, and her inability to conform to the narrative of merit that dominates the school. In part, this might be due to Lee's lack of familiarity with the ideal of sprezzatura-she does not seem to understand that the notion of 'studied effortlessness' does not mean actual effortlessness, but a careful and controlled performance thereof. In any case, Lee's anxieties and her passivity together lead to a condition that could be called dissociation. She feels apart from her surroundings- "no matter what I was doing, I was always imagining something else" (40); refusal becomes a habit for her (93); she is never fully in the moment but always observes herself from a distance- "everything felt peripheral" (40). Lee is increasingly dissociated not only from her environment, but also from her own emotions; even her depression feels "ephemeral; it was possible to be distracted from it by hanging out with Martha, or by listening to a chapel talk, or even - this had to mean it wasn't serious-by watching television" (232).

Reading Prep through the lens of mobility-and as a comment on the discursive dominance and 'normalcy of mobility'-further complicates the novel's position in the neoliberal imagination. The ambivalence of the narrative's engagement with the diversity paradigm is aggravated further by its conflicted treatment of the supposed contingency of class. Both the genre markers of the coming-of-age story and the spatiotemporal structure of the campus novel let the reader expect a number of different 'mobilities': developmental (from adolescence to young adulthood); intellectual (via the superior educational environment Lee finds herself in); identitarian (particularly with regard to class); and socio-economical (upward mobility). The novel, however, belies these expectations almost without exception. While the reader is waiting for that one decisive moment that will inevitably jumpstart Lee's transformation, she goes through the motions-reflecting, commenting, judging herself and her peers, but not undergoing any of the above-mentioned changes.

\section{Concluding Remarks}

This chapter offered a comprehensive reading of Curtis Sittenfeld's novel Prep in order to explore the ways in which the imaginative mode contributes to the epistemology of elite education in twenty-first century America. I decided to 